\title{
Correction: Kynurenine pathway is altered in patients with SLE and associated with severe fatigue
}

Åkesson K, Pettersson S, Ståhl S, et al. Kynurenine pathway is altered in patients with SLE and associated with severe fatigue. Lupus Science E Medicine 2018;5:e00254.

doi: 10.1136/lupus-2017-000254

The authors want to alert readers to the following two errors identified in the published version.

The second sentence in the Conclusions section of the Abstract should read as:

Drugs targeting enzymes in the kynurenine pathway, for example, IDO inhibitors or niacin (B3) supplementation, which suppresses IDO activity, merit further investigation as treatments in SLE.

Again, in the Discussion section, the last sentence of the second paragraph should read as:

In the aim to suppress IDO activity, niacin (vitamin B3) supplementation ${ }^{9}$ and IDO blockers ${ }^{43}$ might be interesting treatment perspectives in SLE.

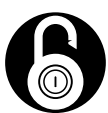

\section{OPEN ACCESS}

Open access This is an open access article distributed in accordance with the Creative Commons Attribution Non Commercial (CC BY-NC 4.0) license, which permits others to distribute, remix, adapt, build upon this work non-commercially, and license their derivative works on different terms, provided the original work is properly cited, appropriate credit is given, any changes made indicated, and the use is non-commercial. See: http://creativecommons.org/licenses/by-nc/4.0/.

Lupus Science \& Medicine 2019;6:e000254corr1. doi:10.1136/lupus-2017-000254corr1

D) Check for updates 